\title{
Environment-specific selection to identify high yielding wheat genotypes and response to fungicide application
}

\author{
Giovani Benin ${ }^{*}$, Lindolfo Storck ${ }^{1}$, Volmir Sergio Marchioro², Elesandro Bornhofen ${ }^{1}$, \\ Leomar Guilherme Woyann ${ }^{1}$, Diego Maciel Trevizan ${ }^{1}$
}

10.1590/0034-737X201764020009

\begin{abstract}
Selection of disease resistant genotypes is the main goal of wheat (Triticum aestivum L.) breeding programs. However, because of the lack of genotypes resistant to all diseases and the strong influence of the environment on the level of resistance of the genotypes, the use of fungicides is necessary in the cultivation of wheat. The objective of this study was to compare the gain in yield and the selection efficiency of wheat genotypes due to the fungicide application in trials carried out in different sites and years. This study used grain yield data from 816 wheat genotypes evaluated in 248 advanced trials at eight sites during the years from 2004 to 2012. The gain resulting from fungicide application for a given genotype was estimated by the difference between yield of plots on which fungicide was applied and control treatment. The greatest gains with fungicide application were observed in sites with lower average temperatures and higher rainfall indices, such as Campo Mourão, Castro, Não-Me-Toque and Guarapuava. On the other hand, the lowest gains with fungicide application occurred in Dourados and Palotina, environments where crops in general suffer water stress and present higher average temperatures. The year effect resulted in yield increases due to fungicide application ranging from 16.9 to $60.7 \%$. The selection and evaluation of the response to the application of fungicide in wheat should be environment-specific to maximize the use of genotype $\mathrm{x}$ environment interaction.
\end{abstract}

Key-words: disease resistance; environment x genotype interaction; genotype selection; Triticum aestivum L.

\section{RESUMO}

\section{Seleção ambiente-específica de genótipos para rendimento de grãos e responsividade à aplicação de fungicida em trigo}

A seleção de genótipos resistentes a doenças é uma meta prioritária dos programas de melhoramento genético de trigo (Triticum aestivum L.). Mas, devido a não existirem genótipos resistentes à todas as doenças e a forte influência do ambiente no nível de resistência dos genótipos, o uso de fungicidas é necessário no cultivo do trigo. O objetivo deste estudo foi comparar o ganho em produtividade e a eficiência da seleção de genótipos de trigo devido à aplicação de fungicida em ensaios realizados em diferentes locais e anos de cultivo. Foram utilizados dados de produtividade de grãos de 816 genótipos de trigo avaliados em 248 ensaios de competição, em oito locais, nas safras agrícolas de 2004 a 2012. O ganho com a aplicação de fungicida para um dado genótipo foi estimado pela diferença entre a produtividade das parcelas que receberam fungicida e o tratamento controle. Os maiores ganhos com a aplicação de fungicida foram observados em locais que apresentam menores temperaturas médias e maiores indíces pluviométricos, tais como Campo Mourão, Castro, Não-Me-Toque e Guarapuava. Já os menores ganhos com a aplicação de fungicidas ocorreram

Submetido em 06/11/15 e aprovado em 21/02/17

1' Universidade Tecnológica Federal do Paraná, Pato Branco, Paraná, Brazil. giovani.bn@gmail.com; lindolfostorck@gmail.com; elesandro.bornhofen@gmail.com; leowoyann@gmail.com; diegotrevizan@alunos.utfpr.edu.br

${ }^{2}$ Cooperativa Central de Pesquisa Agrícola (COODETEC), Cascavel, Paraná, Brazil. volmir@coodetec.com.br

*Corresponding author: benin@utfpr.edu.br 
em Dourados e Palotina, ambientes que geralmente impõem estresses hídricos a cultura e que possuem temperaturas médias mais elevadas. $\mathrm{O}$ efeito de anos de cultivo resultou em incrementos de produtividade devido a aplicação de fungicida que variaram de 16,9 a 60,7\%. A seleção e a avaliação da resposta à aplicação de fungicida em trigo deve ser ambiente-específica, buscando maximizar o aproveitamento da interação genótipo x ambiente.

Palavras-chave: Triticum aestivum L.; interação genótipo x ambiente; seleção de genótipos; resistência a doenças.

\section{INTRODUCTION}

In Brazil, wheat (Triticum aestivum L.) is grown in a range of environments with different soil, weather and management conditions, which affect the cultivars adaptability and the pressure of pathogens, mainly those that cause fungal diseases.

The wide range of fungal diseases that may attack wheat crop presents different potentials of damage to the production and the quality of the grain produced throughout the country. The damage caused by those diseases depends on the growth stage of the crop and the severity of the disease, which is a function of environmental conditions, virulence of the physiological race and the susceptibility of the cultivar (Roelfs et al., 1992). The major diseases of wheat in Brazil are powdery mildew (Blumeria graminis f.sp. tritici), leaf rust (Puccinia recondita f.sp. tritici) and the leaf spot complex, which includes brown spot (Bipolaris sorokiniana), yellow spot (Drechslera tritici-repentis) and glume spot (Stagonospora nodorum). These diseases occur mostly in regions with higher air relative humidity and especially affect the photosynthetic capacity of the plant. The control is usually efficient whem an appropriate crop management is carried out, mainly in relation to crop rotation and choice of fungicides.

In addition to plant's structure diseases, spike diseases such as Fusarium head blight (FHB) (Gibberella zeae) and blast (Pyricularia oryzae) have the potential to prevent the translocation of photoassimilates to the grains and to produce toxins that may be harmful to consumers of the products derived from these grains. FHB is a disease that occurs more frequently in the states of Rio Grande do Sul, Santa Catarina and the coldest regions of Paraná. Blast is more frequent in the warmer regions of Brazil where wheat is grown. Those diseases are difficult of being controlled by fungicides.

The occurrence of diseases in wheat canopy has an important influence on the fluctuations in the production of this cereal, both in Brazil (Tormen et al., 2013) and in other countries (Ilbery et al., 2012). Because of the fungicide aplication costs and its environmental impacts, the main alternative of disease control is the use of resistant cultivars. However, there are no wheat cultivars with a good level of resistance to all diseases and the resistance presented by the cultivars is relative, as it depends on the environmental conditions, which vary among years and regions where it is grown. Fungicide is applied to mitigate the effects of the lack of genetic resistance and unfavorable environmental conditions, such as high pathogen incidence, emergence of new strains of pathogens and pathogen-favorable environmental conditions.

The variation in efficacy and responsiveness to fungicide application is mainly influenced by the relative air humidity, temperature, pathogen aggressiveness, resistance of the cultivar and the level of technological management adopted (Barros et al., 2006; Jørgensen \& Olsen 2007; Loyce et al. 2008; Wegulo et al., 2011; Thompson et al., 2014). Depending on the conditions of the environment, management and cultivars, losses ranging from 5.5 to $79 \%$ due to the occurrence of leaf fungal diseases were recorded (Ransom \& Mcmullen 2008; Wegulo et al. 2009; MacLeod et al., 2010; Tonin et al., 2013). The losses in productivity are mainly due to the early senescence and to the lower interception and efficiency of the use of solar radiation (Serrago et al., 2009; Zhang et al., 2010; Serrago et al., 2011).

The environmental variability and differentiated responses of genotypes to fungicide application makes it necessary to identify specific sites for the selection of cultivars and the evaluation of the effectiveness of this practice. In breeding programs, selection of cultivars and their responses to fungicide application is carried out in experimental units (Kurt, 2002). Value for Cultivation and Use (VCU) tests are generally conducted with one or more fungicide applications, for maximum expression of the genotype, without the interference of diseases, and in one or more replicates, no fungicide is applied. In these plots where no protection is used, the reduction in productivity may vary significantly, according to the degree of resistance of the cultivars and the environmental conditions.

The objective of this study was to determine the gain in wheat yield due to the application of fungicides in different years and cultivation sites, and to qualify environments that enhance the selection of genotypes that are more resistant and/or responsive to fungicide application. 


\section{MATERIALAND METHODS}

We used data from grain yield of 816 wheat genotypes (90 cultivars and 726 lines) evaluated in 248 trials at eight growing sites in crop seasons from 2004 to 2012. The tests were conducted in Abelardo Luz, state of Santa Catarina (ABL), Campo Mourão in the state of Paraná (CMR), Cascavel, state of Paraná (CSC), Castro, state of Paraná (CST), Dourados, state of Mato Grosso do Sul (DRD), Guarapuava, state of Paraná (GVA), Não-Me-Toque, state of Rio Grande do Sul (NMT) and Palotina, state of Paraná (PTN). The sites differ regarding to altitude, latitude and longitude (Table 1), rainfall and temperature (Figure 1), and are representative of the VCU 1 (CST, GVA, NMT), VCU 2 (ABL, CMR, CSC) and VCU 3 (DRD, PTN) region. The genotypes were evaluated in the Value for Cultivation and Use (VCU) network of the wheat breeding program from the Central Agricultural Cooperative for Economic and Social Development (COODETEC).

The trials were carried out using a randomized complete block design and each one consisted of 25 genotypes distributed in three blocks with fungicide and one block with no fungicide application. The plots consisted of six lines of $5.0 \mathrm{~m}$ length, spaced by $0.20 \mathrm{~m}$ apart. Crop management and application of fungicides were carried out according to the technical information for the wheat crop in each evaluation year (RCBPTT, 2008). Because the tests were conducted in different regions, with occurrence of different diseases, the number of preventive applications ranged from 3 to 5, carried out at the same time for all genotypes, aiming at a more effective control of diseases at any growth stage. At maturity, harvest was carried out and grain yield $\left(\mathrm{kg} \mathrm{ha}^{-1}\right)$ was measured, corrected at $13 \%$ of moisture.

Gain $(\mathrm{G})$ in grain yield in the blocks where fungicide was applied in relation to the same genotype in the block with no application of the fungicide, for each trial and genotype, was estimated using the expression: $G_{i j}=100\left(Y_{i j}\right.$ - $Y_{i 4}$ ) / $Y_{i 4}$ for the production (Y) for the genotype $i$ in blocks $j=1,2$ and 3 (with fungicide) and $=4$ (with no fungicide).

The two characters ( $Y$ and $G$ ), with three replicates, were submitted to analysis of variance according to the randomized complete block design. The selective accuracy was calculated using the expression: $\mathrm{SA}=(1-1 / \mathrm{F})^{0.5}$ where $\mathrm{F}=$ value of the $\mathrm{F}$ test for genotypes in the analysis of variance (Resende \& Duarte, 2007).

The semi-amplitude of the confidence interval was estimated using the expression: $d=z \frac{\sigma}{\sqrt{n}}$, where $z=1.96$ for $95 \%$ of confidence, $\sigma$ is the standard deviation for the set of evaluated individuals and $n$ indicates the number of individuals evaluated.

The genotypes were divided into two percentiles $\left(\mathrm{P}_{0.05}\right.$ and $\left.\mathrm{P}_{0.95}\right)$, where $\mathrm{P}_{0.05}$ is the group of genotypes less responsive to the application of fungicides and $\mathrm{P}_{0.95}$ is the most responsive group. The genotypes were also divided into classes according to the percentage gain in yield and yield regarded to overall average yield. In the first division, two classes were formed, one composed of genotypes with gain in yield with lower application of fungicide and the other higher than the overall average, which was $36.3 \%$. In the second division, the two classes were composed of genotypes with lower and higher yield than the general average $\left(3.380 \mathrm{~kg} \mathrm{ha}^{-1}\right)$. The sites are considered significantly different when the mean + CI (half range of the confidence interval, $1-p=0.95$ ) of one site is less than the average - CI of another location. Statistical analyzes were performed in the Genes program (Cruz, 2013) and figures elaborated in the Sigmaplot v.11 software.

\section{RESULTS AND DISCUSSION}

The genotype effect on grain yield and gain due to fungicide application was significant $(\mathrm{p}<0.05)$ in $100 \%$ of the tests (Table 2). This indicates that, regardless of the cultivation site or the year of evaluation, a variation was found among the genotypes regarding the response to

Table 1: Test sites for evaluation of wheat genotypes with the respective Value for Cultivation and Use (VCU) regions, geographic coordinates, altitude, sowing date and average cycle of genotypes

\begin{tabular}{|c|c|c|c|c|c|c|c|}
\hline \multirow{2}{*}{ Site (City, State) } & \multirow{2}{*}{ Abbreviatiom } & \multirow{2}{*}{ VCU Region } & \multicolumn{2}{|c|}{ Coordinates } & \multirow{2}{*}{$\frac{\text { Altitude }}{\mathrm{m}}$} & \multirow{2}{*}{$\begin{array}{c}\text { Sowing } \\
\text { date }\end{array}$} & \multirow{2}{*}{$\begin{array}{l}\text { Cycle } \\
\text { days } \dagger\end{array}$} \\
\hline & & & Lat. & Long. & & & \\
\hline $\begin{array}{l}\text { Castro, PR } \\
\text { PR }\end{array}$ & CST & 1 & $24^{\circ} 47^{\prime} \mathrm{S}$ & $50^{\circ} 00^{\prime} \mathrm{W}$ & 988 & Jun. 15 & 130 \\
\hline Guarapuava, PR & GVA & 1 & $25^{\circ} 23^{\prime} \mathrm{S}$ & $51^{\circ} 27^{\prime} \mathrm{W}$ & 1120 & Jun. 20 & 132 \\
\hline Não-Me-Toque, RS & NMT & 1 & $28^{\circ} 27^{\prime} \mathrm{S}$ & $52^{\circ} 49^{\prime} \mathrm{W}$ & 514 & Jun. 10 & 130 \\
\hline Abelardo Luz, SC & $\mathrm{ABL}$ & 2 & $26^{\circ} 33^{\prime} \mathrm{S}$ & $52^{\circ} 19^{\prime} \mathrm{W}$ & 760 & Jun. 15 & 128 \\
\hline Campo Mourão, PR & CMR & 2 & $24^{\circ} 02^{\prime} \mathrm{S}$ & $52^{\circ} 22^{\prime} \mathrm{W}$ & 630 & May. 10 & 123 \\
\hline Cascavel, PR & $\mathrm{CSC}$ & 2 & $25^{\circ} 57^{\prime} \mathrm{S}$ & $53^{\circ} 27^{\prime} \mathrm{W}$ & 785 & Mai. 10 & 125 \\
\hline Dourados, MS & DRD & 3 & $22^{\circ} 13^{\prime} \mathrm{S}$ & $54^{\circ} 48^{\prime} \mathrm{W}$ & 430 & Apr. 10 & 112 \\
\hline Palotina, PR & PTN & 3 & $24^{\circ} 17^{\prime} \mathrm{S}$ & $53^{\circ} 50^{\prime} \mathrm{W}$ & 335 & Apr. 20 & 118 \\
\hline
\end{tabular}

$\S$ Approximate sowing date. †Average cycle from sowing to physiological maturity. 

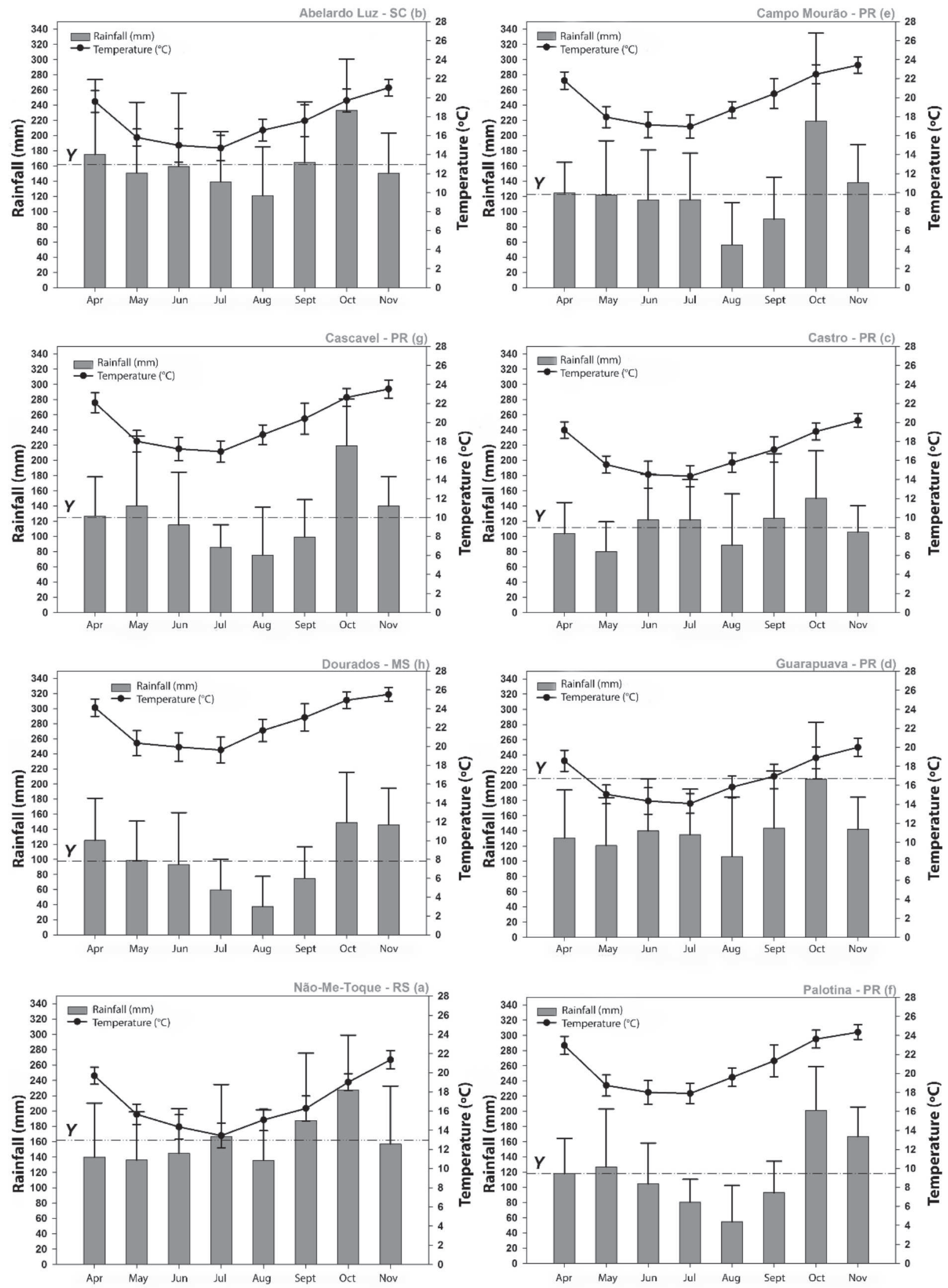

Figure 1: Weather scenario, including monthly rainfall and temperature from 2004 to 2012 for eight wheat test sites. Deviations within the figures point to oscillation in relation to the nine-year average. Y: rainfall average between April and November, from 2004 to 2012 .

Rev. Ceres, Viçosa, v. 64, n.2, p. 167-175, mar/abr, 2017 
fungicide application, with the possibility of selection of genotypes that are more resistant and/or responsive to phytosanitary management.

Yield gain due to fungicide application exceeded the control yield (without fungicide) by $100.5 \%$ in $5 \%$ of the tests, indicating the presence of genotypes that are susceptible to diseases and highly responsive to application of genotypes (Table 2). In addition, in $5 \%$ of the trials, the gain with the application of fungicide was less than $2.5 \%$, which may indicate, in these tests, the presence of genotypes more resistant to diseases and/or environments (sites and years) less favorable to the development of pathogens. These results show that the management of diseases with fungicides results in significant gains in grain yield.

The overall average of yield gain with fungicide application was $36.3 \%$. The selective accuracy (SA), which evaluates the accuracy of the tests (Resende \& Duarte, 2007), was $81.9 \%$ in the $5 \%$ less responsive to fungicide application genotype group and $99.4 \%$ in the $5 \%$ more responsive to fungicide application genotype group (Table 2). The highest SA in the 5\% more responsive group is due to the greater amplitude of response variability of the genotypes to the fungicide, raising the mean square of genotype in the analysis of variance and, consequently, the calculated $F$ value. The overall mean of SA was $94.4 \%$, indicating high experimental accuracy in genotype selection. In the same groups, the SA for the grain yield character was lower than the SA for the gain due to the application of fungicide, indicating that the grain yield is more dependent on the environmental variation.

In this study, the influence of the environmental effect (sites and years of cultivation) on the productive performance of wheat and on the response to fungicide application was evidenced (Table 3). Wegulo et al. (2011) also observed that the environmental component is important and highly dependent on the site and year of cultivation. In Table 3, Dourados was the site with the lowest grain yield average $\left(2,811 \mathrm{~kg} \mathrm{ha}^{-1}\right)$ and it showed the lowest gain with fungicide application (4.3\%). The lower yield and responsiveness to the application of fungicide in Dourados is because of the lower rainfall and higher average temperature (Figure 1), which negatively influence grain yield, since they submit wheat to water and temperature stress, reducing the cycle (Table 1) and the grain-filling period. The application of fungicide in low yield environments and where diseaseunfavorable factors predominate combined with the use of resistant genotypes, may compromise the economic viability of this practice (Wegulo et al., 2011; Thompson et al., 2014). In a study with a cultivar that was little affected by leaf rust, Assunção \& Torres (2013) also emphasize the need to adopt action thresholds, considering the economic return of this practice and the rational use of fungicides.

The highest gain with fungicide application, 56.9\% (Table 3), was observed in Campo Mourão, a municipality that belongs to the Ivaí river basin (SEMA, 2010). Rivers of significant size are present in the territory of the municipality, which, allied with the combination of mild temperatures and moderate rainfall rates (Figure 1), results in ideal relative humidity indexes for the development of pathogens. A similar condition occurs in Castro, located in the Tibagi river basin (SEMA, 2010). In these two sites, wheat is influenced by the highest rainfall accumulations in September and October (Figure 1), submitting crops to conditions predisposed to the occurrence of diseases. In contrast, wheat harvest in Palotina and Dourados is carried out before the rainy season, because of early sowing, resulting in a lower incidence of diseases.

The highest yields and gains with the application of fungicides were found in Castro and Guarapuava, (Table

Table 2: Characterization and clustering of Value for Cultivation and Use trials (VCU) of wheat based on the average of wheat grain yield (Yield, $\mathrm{kg} \mathrm{ha}^{-1}$ ), selective accuracy for yield (Yield (SA\%)), gain due to fungicide application (Gain (\%)) and selective accuracy for gain (SA\%)

\begin{tabular}{|c|c|c|c|c|}
\hline Statistic $^{(1)}$ & Yield (kg ha $\left.{ }^{-1}\right)$ & Yield (SA\%) & Gain $(\%)$ & Gain (SA\%) \\
\hline $\mathrm{P}_{0.05}$ & 2079 & 63.8 & 2.5 & 81.9 \\
\hline $\mathrm{P}_{0.95}$ & 4687 & 97.6 & 100.5 & 99.4 \\
\hline Average & 3380 & 86.6 & 36.3 & 94.4 \\
\hline Freq. (H1) & $94 \%$ & - & $100 \%$ & - \\
\hline \multicolumn{5}{|c|}{ Number of genotypes classified by yield (Yield, $\mathrm{kg} \mathrm{ha}^{-1}$ ) and gain } \\
\hline Classes/classes & Yield $<3380$ & Yield $>3380$ & Sum & Total (\%) \\
\hline Gain $<36.3 \%$ & 283 & 230 & 513 & 63 \\
\hline Gain $>36.3 \%$ & 196 & 107 & 303 & 37 \\
\hline Sum & $479(59 \%)$ & $337(41 \%)$ & 816 & 100 \\
\hline
\end{tabular}


3). These sites are located at altitudes higher than $1.000 \mathrm{~m}$ (Table 1), submitting the wheat crop to mild temperatures throughout its cycle (Figure 1), which, combined with the greater availability of incident solar radiation, results in a high photothermal coefficient $(\mathrm{PC}$ - relationship between solar radiation and temperature) (Cunha et al. 2005; Silva et al. 2014). Sites with high PC allow the elongation of growth subphases and consequently greater differentiation of yield components (Fischer, 1985; Gaju et al. 2009). The longest grain-filling period at sites with the highest PC also promotes the responsiveness to fungicide application (Barkley et al., 2014). In these regions, due to favorable conditions for the occurrence of foliar and FHB diseases, control with fungicide is usually more intense, requiring a greater number of applications.

The environmental variability due to the effect of years of cultivation presented an amplitude of variation of 16.9 to $60.7 \%$ in the gains in grain yield with the application of fungicide. Pearson's linear correlation between the grain yield obtained over the years and the respective gain by the application of fungicide is negative $(\mathrm{r}=-0.70, \mathrm{p}<0.01)$ (data not shown). This shows us that in years where the occurrence of diseases is high, even with the existence of gains with the application of fungicide, the grain yield is expressively reduced. The effect of years of cultivation on the occurrence of diseases in wheat, because of environmental variations, is also reported by other authors (Felicio et al. 2004; Barros et al. 2006; Ransom \& McMullen 2008; Wegulo et al. 2011). In this sense, Thompson et al. (2014) suggest that the phytosanitary management is year/site specific, considering the expected yield potential, prices and predominant climatic conditions.

The effect of the cultivation sites on the yield performance and gain with the application of fungicide can be observed in Figure 2. The lines dividing the quadrants were plotted on the overall grain yield mean and the overall average of yield gain with the application of fungicide. In quadrants 1 and 2 are located the genotypes with grain yield above average, with lower and higher gain due the fungicide application, respectively. In quadrants 3 and 4 are located the genotypes with grain yield below the overall average, with lower and higher gain due the fungicide application, respectively. The dot dispersion refers to the genotypes evaluated at each site over the years. It is observed that Dourados and Palotina presented most of the genotypes concentrated in quadrant 3 , that is, with yield below the overall average and little

Table 3: Number of genotypes $(\mathrm{N})$, grain yield (Yield, $\mathrm{kg} \mathrm{ha}^{-1}$ ), semi-amplitude of confidence interval for grain yield (YCI, $\left.\mathrm{kg} \mathrm{ha}^{-1}\right)$, gain $(\%)$ due to the fungicide application in Value for Cultivation and Use trials (VCU) of wheat, semi-amplitude of confidence interval for gain $(\mathrm{GCI} \%)$ for test sites and year

\begin{tabular}{|c|c|c|c|c|c|}
\hline & $\mathbf{N}^{(1)}$ & Yield & $\mathrm{YCI} \dagger$ & Gain (\%) & GCI \\
\hline \multicolumn{6}{|l|}{ Sites of test } \\
\hline Abelardo Luz & 550 & 3806 & 45 & 30.2 & 2.0 \\
\hline Campo Mourão & 425 & 3200 & 58 & 56.9 & 5.2 \\
\hline Cascavel & 1500 & 3324 & 26 & 37.4 & 2.5 \\
\hline Castro & 500 & 4124 & 67 & 50.4 & 3.1 \\
\hline Dourados & 375 & 2811 & 41 & 4.3 & 1.4 \\
\hline Guarapuava & 700 & 3886 & 48 & 40.5 & 2.6 \\
\hline Não-Me-Toque & 675 & 3454 & 31 & 47.6 & 4.3 \\
\hline Palotina & 1475 & 2946 & 24 & 27.6 & 1.3 \\
\hline Average & 775 & 3443.8 & 42.5 & 36.86 & 2.8 \\
\hline Amplitude & $375-1500$ & $2811-4124$ & $24-67$ & $4.3-56.9$ & $1.3-5.2$ \\
\hline \multicolumn{6}{|l|}{ Years of test } \\
\hline 2004 & 500 & 3163 & 54 & 41.4 & 2.5 \\
\hline 2005 & 450 & 2579 & 37 & 60.7 & 7.4 \\
\hline 2006 & 475 & 3315 & 40 & 51.0 & 3.7 \\
\hline 2007 & 550 & 3400 & 40 & 26.0 & 1.9 \\
\hline 2008 & 900 & 3688 & 46 & 34.8 & 3.2 \\
\hline 2009 & 625 & 3027 & 38 & 53.3 & 2.8 \\
\hline 2010 & 950 & 4006 & 34 & 25.1 & 1.8 \\
\hline 2011 & 950 & 3267 & 30 & 38.1 & 2.5 \\
\hline 2012 & 800 & 3306 & 40 & 16.9 & 1.6 \\
\hline Average & 689 & 3306 & 40 & 38.58 & 3.0 \\
\hline Amplitude & $450-950$ & $2579-4006$ & $30-54$ & $16.9-60.7$ & $1.6-7.4$ \\
\hline
\end{tabular}

$\dagger$ YCI: semi-amplitude of the confidence interval $(1-\mathrm{p}=0.95) ;{ }^{(1)} \mathrm{N}$ : number of genotypes in each site or year.

Rev. Ceres, Viçosa, v. 64, n.2, p. 167-175, mar/abr, 2017 

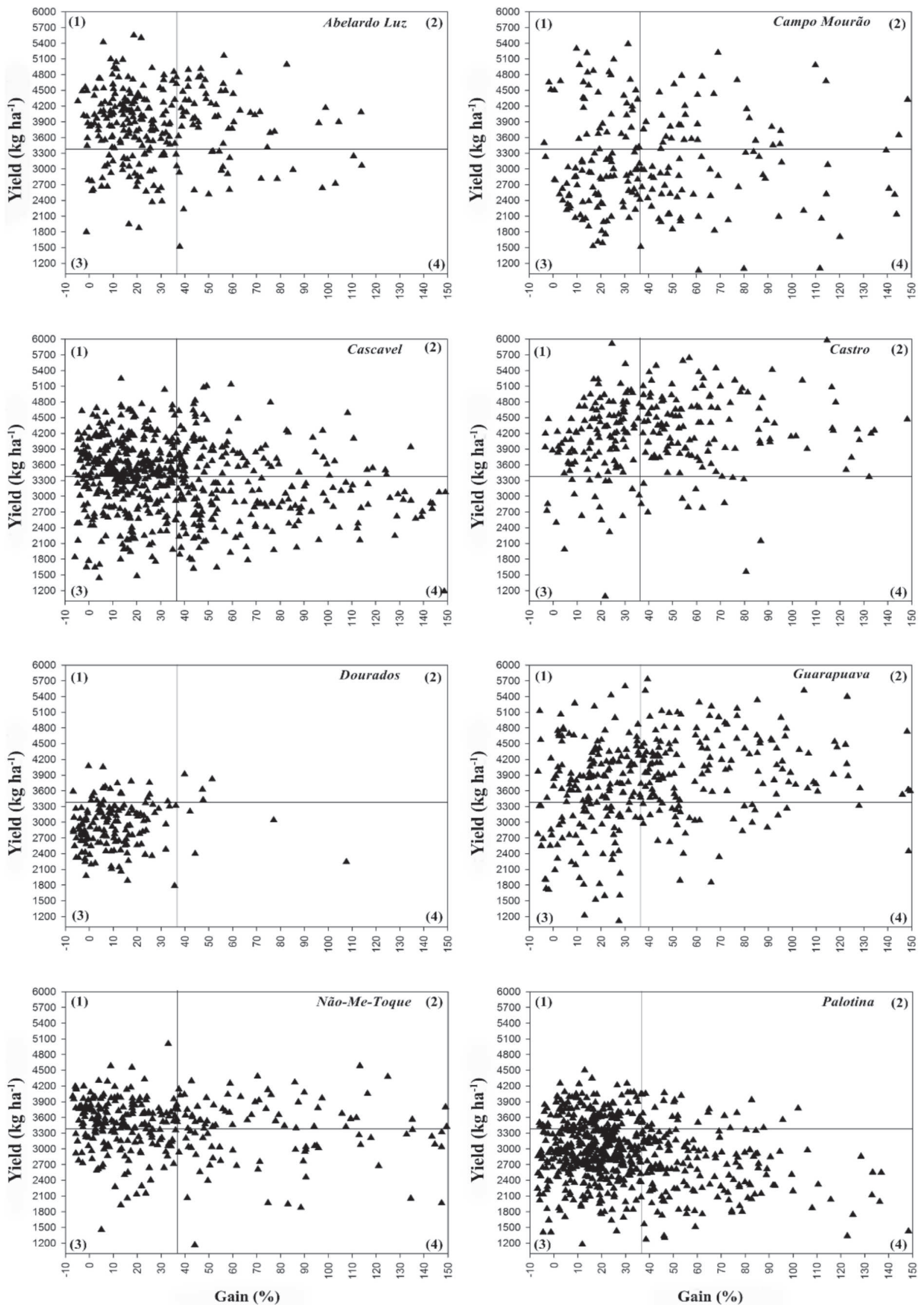

Figure 2: Scatter plots representing grain yield dispersion and response to fungicide aplication (Gain (\%)) of 814 wheat genotypes evaluated in eight sites, during the years from 2004 to 2012. Numbers between parentheses (1 to 4) are the genotype performance. Genotypes with low gain due to fungicide application and with high and low yields are in quadrants 1 and 3, respectively. In quadrants 2 and 4, it can be found the genotypes with high gain due to fungicide application with high and low yields, respectively. 
responsive to the application of fungicide, due to the limitation of these environments (Figure 1). The low response variability of the genotypes to the application of fungicide is justified itself because these sites showed the lowest grain yields and the lowest gains in productivity with the application of fungicide (Table 3).

We verified in Castro, Guarapuava and Abelardo Luz, a higher concentration of genotypes in quadrants 1 and 2 , that is, above the overall yield average and little or high responsive to the application of fungicide, respectively. Thus, in environments that are more favorable to wheat crop, such as Castro, Guarapuava and Abelardo Luz, the breeder has a wide range of variation among genotypes, being able to prioritize the selection of genotypes with high grain yield, with greater resistance to diseases (quadrant 1) or responsive to application of fungicide (quadrant 2). Cascavel, Não-Me-Toque and Campo Mourão present similar characteristics regarding stratification of genotypes, with a higher concentration of genotypes in quadrants 1 and 2, however, allowing the identification of responsive genotypes for fungicide application.

These results indicate that the response of wheat to fungicide application is highly variable since it depends on several factors, such as the incidence and severity of specific leaf diseases, resistance of cultivars, yield potential and environmental conditions. It was observed a great effect of years and growth sites on the yield performance of the wheat crop and responsiveness to the application of fungicide, corroborating with studies conducted by Wegulo et al. (2011), Barkley et al. (2014) and Thompson et al. (2014). Brancourt-Hulmel et al. (2005), Loyce et al. (2008, 2012) and Thompson et al. (2014) also observed the need for local-specific selection and evaluation, to maximize the use of the genotype $\mathrm{x}$ environment interaction. In order to maximize and optimize the selection, it is important that the experimental network includes discriminatory sites (that potentiate the differentiation of genotypes) and representative of the region of cultivation.

\section{CONCLUSIONS}

The evaluation of the response to fungicide application in the selection of wheat genotypes for yield should be environment-specific and the tests should be carried out in different sites and years to quantify and capitalize the genotype $\mathrm{x}$ environment interaction in the selection process.

In the experimental network of wheat breeding programs, there should be sites that maximize and allow the selection of genotypes resistant to diseases and, in addition, responsive to the application of fungicides.

\section{REFERENCES}

Assunção M \& Torres AL (2013) Eficácia versus viabilidade econômica do controle químico e genético da ferrugem da folha em trigo. Ciência Rural, 43:1141-1146.

Barkley A, Tack J, Nalley LL, Bergtold J, Bowden R \& Fritz A (2014) Weather, disease, and wheat breeding effects on Kansas wheat varietal yields, 1985 to 2011. Agronomy Journal, 106:227-235.

Barros BC, Castro JL \& Patrício FRA (2006) Resposta de cultivares de trigo (Triticum aestivum L.) ao controle químico das principais doenças fúngicas da cultura. Summa Phytopathologica, 32:239-246.

Brancourt-Hulmel M, Heumez E, Pluchard P, Beghin D, Depatureaux C, Giraud A \& Le Gouis J (2005) Indirect versus direct selection of winter wheat for low-input or high-input levels. Crop Science, 45:1427-1431.

Cunha FR, Pires JLF, Pasinato A \& Dalmago GA (2005) Variabilidade temporal e espacial do quociente fototermal no Rio Grande do Sul e suas implicações para a expressão do potencial de rendimento de grãos de trigo. Revista Brasileira de Agrometeorologia, 13:91-101.

Cruz CD (2013) GENES - a software package for analysis in experimental statistics and quantitative genetics. Acta Scientiarum. Agronomy, 35:271-276.

Del Ponte EM, Fernandes J, Pavan W \& Baethgen WE (2009) A model based assessment of the impacts of climate variability on fusarium head blight seasonal risk in Southern Brazil. Journal of Phytopathology, 157:675-681.

Felicio JC, Camargo CEO, Castro JLD \& Germani R (2004) Rendimento de grãos de trigo e sua relação com as doenças e variáveis climáticas em Capão Bonito de 1994 a 2001. Bragantia, 63:93-103.

Fischer RA (1985) Number of kernels in wheat crops and the influence of solar radiation and temperature. Journal of Agricultural Science, 105:447-461.

Gaju O, Reynolds MP, Sparkes DL \& Foulkes MJ (2009) Relationships between large-spike phenotype, grain number, and yield potential in spring wheat. Crop Science 49:961-973.

Goulart ACP, Sousa PG \& Urashima AS (2007) Danos em trigo causados pela infecção de Pyricularia grisea. Summa Phytopathologica, 33:358-363.

Ilbery B, Maye D \& Little R (2012) Plant disease risk and groweragronomist perceptions and relationships: an analysis of the UK potato and wheat sectors. Applied Geography, 34:306-315.

Jørgensen LN \& Olsen LV (2007) Control of tan spot (Drechslera tritici-repentis) using cultivar resistance, tillage methods and fungicides. Crop Protection, 26:1606-1616.

Kurt S (2002) Screening of wheat cultivars for resistance to stripe rust and leaf blotch in Turkey. Crop Protection, 21:495-500.

Loyce C, Meynard JM, Bouchard C, Rolland B, Lonnet P, Bataillon P, Bernicot MH, Bonnefoy M, Charrier X, Debote B, Demarquet T, Duperrier B, Félix I, Heddadj D, Leblanc O, Leleu M, Mangin P, Méausoone M \& Doussinault G (2012) Growing winter wheat cultivars under different management intensities in France: A multicriteria assessment based on economic, energetic and environmental indicators. Field Crops Research, 125:167-178.

Loyce C, Meynard JM, Bouchard C, Rolland B, Lonnet P, Bataillon P, Bernicot MH, Bonnefoy M, Charrier X, Debote B, Demarquet T, Duperrier B, Félix I, Heddadj D, Leblanc O, Leleu M, Mangin P, Méausoone M, \& Doussinault G (2008) Interaction between cultivar and crop management effects on winter wheat disease, lodging and yield. Crop Protection, 27:1131-1142. 
MacLeod A, Pautasso M, Jeger MJ \& Haines-Young R (2010) Evolution of the international regulation of plant pests and challenges for future plant health. Food Security, 2:49-70.

Ransom JK \& McMullen MV (2008) Yield and disease control on hard winter wheat cultivars with foliar fungicides. Agronomy Journal, 100:1130-1137.

RCBPTT - Reunião da Comissão Brasileira de Pesquisa de Trigo e Triticale (2008) Informações técnicas para a safra 2009: trigo e triticale. Passo Fundo, RCBPTT / Embrapa Trigo / Embrapa Transferência de Tecnologia. 172p.

Resende MDV \& Duarte JB (2007) Precisão e controle de qualidade em experimentos de avaliação de cultivares. Pesquisa Agropecuária Tropical, 37:182-194.

Roelfs AP, Singh RP \& Saari EE (1992) Rust Diseases of Wheat: Concepts and methods of disease management. Mexico, CIMMYT. $81 \mathrm{p}$.

SEMA (2010) Bacias hidrográficas do Paraná - Série histórica. Curitiba, SEMA. 138p.

Serrago RA, Carretero R, Bancal MO \& Miralles DJ (2009) Foliar diseases affect the eco-physiological attributes linked with yield and biomass in wheat (Triticum aestivum L.). European Journal of Agronomy, 31:195-203.

Serrago RA, Carretero R, Bancal MO \& Miralles DJ (2011) Grain weight response to foliar diseases control in wheat (Triticum aestivum L.). Field Crops Research, 120:352-359.
Silva RR, Benin G, Marchese JA, Silva ÉDBD \& Marchioro VS (2014) The use of photothermal quotient and frost risk to identify suitable sowing dates for wheat. Acta Scientiarum. Agronomy, 36:99-110.

Thompson NM, Epplin FM, Edwards JT \& Hunger RM (2014) Economics of foliar fungicides for hard red winter wheat in the USA southern Great Plains. Crop Protection, 59:01-06.

Tonin RFB, Reis EM \& Danelli ALD (2013) Etiologia e quantificação dos agentes causais de manchas foliares na cultura do trigo nas safras 2008 a 2011. Summa Phytopathologica, 39:102-109.

Tormen NR, Lenz G, Minuzzi SG, Uebel JD, Cezar HS \& Balardin RS (2013) Reação de cultivares de trigo à ferrugem da folha e mancha amarela e responsividade a fungicidas. Ciência Rural, 43:239-246

Wegulo SN, Breathnach JA \& Baenziger PS (2009) Effect of growth stage on the relationship between tan spot and spot blotch severity and yield in winter wheat. Crop Protection, 28:696702 .

Wegulo SN, Zwingman MV, Breathnach JA \& Baenziger PS (2011) Economic returns from fungicide application to control foliar fungal diseases in winter wheat. Crop Protection, 30:685-692.

Zhang YJ, Zhang X, Chen CJ, Zhou MG \& Wang HC (2010) Effects of fungicides JS399-19, azoxystrobin, tebuconazole, and carbendazim on the physiological and biochemical indices and grain yield of winter wheat. Pesticide Biochemistry and Physiology, 98:151-157. 